\title{
ADAPTATION OF THE IDEA OF PHRONESIS IN CONTEMPORARY APPROACH TO INNOVATION
}

\author{
Aleksandra KUZIOR \\ Silesian University of Technology \\ Ján ZOZUL'AK \\ Constantine the Philosopher University in Nitra
}

\begin{abstract}
:
The article is devoted to the importance of the virtue of prudence and attempts to adapt it in the contemporary discourse on innovation and sustainable development. The authors come from ancient roots, recalling the positions of Socrates, Plato and, above all, Aristotle. They point to the renewed interest of contemporary researchers in the ethics of virtues and point to the important roles of prudence, prudence and responsibility in the approach to innovation. Innovations are captured as an instrumental value and a tool to shape better living conditions, work, study, rest, all forms of human activity and environmental protection. Therefore, their positive character has been exposed, although the authors also pay attention to the risk and possibility of negative effects if the virtues of nature, such as prudence, caution and responsibility are not well-formed. The authors point out that this is particularly important in the education of engineers who shape the innovative landscape of the present, and prove that this applies to mechatronics or robotics specialists, as well as production engineering specialists, because the ethical approach allows for the appropriate design of the entire team of activities from recognizing the need to satisfy it through an efficient, well-prepared, organized and properly managed production process, taking into account the basic principles of sustainable development.
\end{abstract}

Key words: ethics, human action, innovation, prudence (phronesis), sustainable development, virtues

\section{INTRODUCTION}

The article ${ }^{1}$ at hand deals with the topic of prudence -

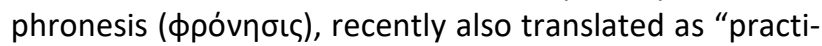
cal wisdom", in relation to innovation as a value. We will outline the philosophical context of prudence as a practical discipline, proceeding from the ancient Greek philosophy, in which the primary meaning of the word

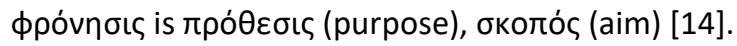

The issue of prudent human acts is highly topical today, with multiple authors currently paying attention to it [3, $10,11]$. The essence of moral virtue, closely linked to the issue of prudence, is considered an issue of ethics within the framework of ancient philosophy. In the life of the Greek polis, this issue was also understood as a sum of attributes and activities, by which an individual demonstrated his being a good member of the community [5]. In Socrates, virtue, in relation to the social and moral action, is seen as human thought related to the realization of moral values. Virtue, according to Socrates, is knowledge

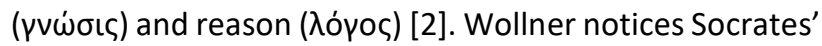
notion of self-care, which converged in two virtues: tem-

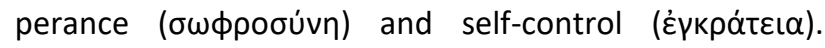

Through these two virtues, a man is to be able to control

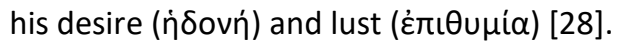

Plato differentiated between four main virtues: prudence

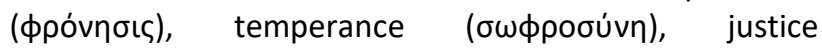

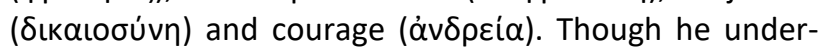
stood the term prudence ( $\phi \rho o ́ v \eta \sigma \iota)$ ) as equal to the term wisdom ( $\sigma \circ \phi i \alpha)$; Xenocrates, on the other hand, states that there is a distinction between the two. Stoics did not make a sharp distinction between the terms wisdom

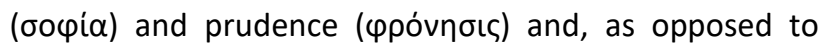
Plato, refused to hierarchize individual virtues, seeing all of them as closely interrelated [13].

Aristotle distinguished between moral and intellectual (dianoetic) virtues. He lists five dianoetic virtues: techne-

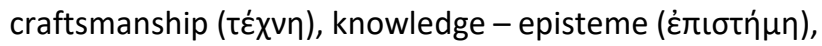

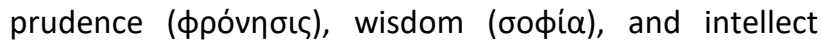
(voũc) [2], and provides a brief characteristic for each of them. We will focus our attention on prudence

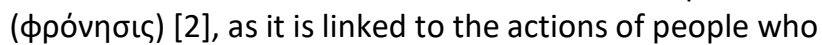

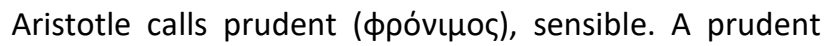
man is able to contemplate about what is good and useful 
to him [2], therefore, prudence must be sought in exceptionally well-developed judgement [4]. Aristotle even cla-

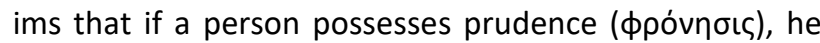
possesses all moral virtues [2]. Virtue is also connected to knowledge. Knowledge, especially self-knowledge, heals and cultivates the innermost core of human personality, psyche; moral effort cannot therefore be disconnected from the seeking of truth [8].

\section{MORAL VIRTUE AND PRUDENCE}

The relation between a moral virtue and prudence ( $\phi \rho o ́ v \eta \sigma \iota \varsigma)$ is one of the cornerstone questions of the Aristotelian ethical treatises Nicomachean Ethics [7] (HӨıќ́

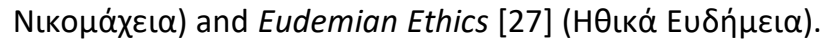
It seems that Aristotle talks about moral virtue differently in the second and sixth book of Nicomachean Ethics, which could lead to two different, even contradictory ethical theories. According to George Karamanolis, who has carried out a detailed analysis of the relationship between moral virtue and prudence within the Aristotelian ethics, there is a distinctive link between the two, on the basis of which prudence ( $\phi \rho \operatorname{vov}_{\mathrm{v}} \mathrm{\iota}$ ) is the essence of the moral virtue, not just its attribute. He is confident that "Aristotelian theory on moral virtue and the relationship between moral virtue and prudence is uniform, at least within the confines of Aristotle's ethical treatise Nicomachean Ethics" [18]. In this regard, he asks himself: Is there a moral virtue without prudence? [18].

In the second book of the Nicomachean Ethics, Aristotle states that moral virtue is a voluntary disposition - hexis

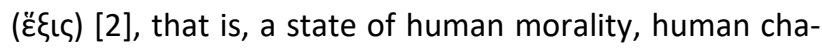
racter. This means that moral virtue is understood as a disposition of human character, which determines exactly how a human will act and react in various situations. Moral virtue is introduced here as a practical activity, acquired by education and training. The term $\varepsilon$ है $\iota \varsigma$ is etymologically linked to the word है $\chi \omega$, meaning to have, to possess. This stance on virtue is based on the distinction between moral and dianoetic virtue, i.e. between virtue of character and virtue of intellect [2]. It seems that moral virtue, the virtue of character, requires not as much understanding and logical reasoning as the education and training from an early age for the human do act well [2], because prudence ( $\phi \rho o ́ v \eta \sigma \iota)$ ) is acquired over time and with experience. "The young may be experts in geometry and mathematics and similar branches of knowledge, we do not consider that a young man can have Prudence. The reason is that Prudence includes a knowledge of particular facts, and this is derived from experience, which a young man does not possess; for experience is the fruit of years" [2]. It is therefore understandable that Aristotle disagrees with Plato and believes in importance of proper upbringing [2].

In the second book of the Nicomachean Ethics, Aristotle talks about choice ( $\pi \rho \circ \alpha i \rho \varepsilon \sigma \mathrm{v})$ [2], specifically, a rational choice [5] or decision ${ }^{2}$ [15], on the basis of which a person carries out a good deed and, at the same time, links moral

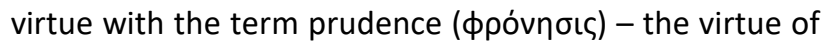

practical activity, which, in contrast to other attributes of the definition, appears for the first time in the discussion on the character of a moral virtue [18]. Moral virtue is thus defined as a "settled disposition of the mind determining the choice of actions and emotions, consisting essentially in the observance of the mean relative to us, this being determined by principle, that is, as the prudent man would determine it" [2]. This means that a moral virtue is defined as a choice of a practical reasoning in the way a

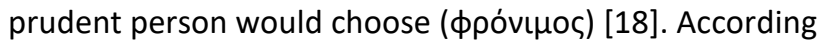
to Boháček, choice ( $\pi \rho \circ \alpha i \rho \varepsilon \sigma \iota)$ ) is the key element of the process leading to successful life and is provided for by prudence [4].

In the sixth book of the Nicomachean Ethics, Aristotle again opens the topic of the moral virtue and immediately

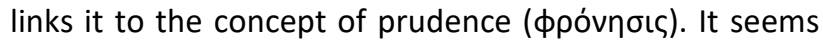
that the moral virtue is no longer purely a "settled dispo-

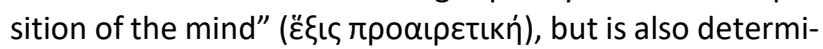
ned by the term prudence ( $\phi \rho o ́ v \eta \sigma \iota \varsigma)$, the virtue of practical action. Moral virtue requires prudence, i.e. there is a link and reciprocal dependence between moral virtue and prudence, as for carrying out a good deed, their cooperation is necessary [2]. From this, it proceeds that moral virtue here has a much deeper dianoetic character [18].

On the basis of detailed analysis of the relation between the moral virtue and prudence in Aristotelian ethics, Karamanolis concludes that "for Aristotle, moral virtue is rational (入оүски́) in essence, what can be seen from the fact that, according to Aristotle, rational choice causes certain

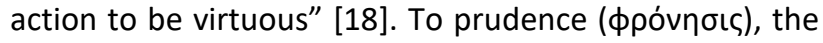

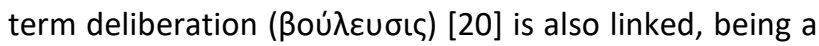

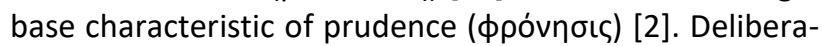

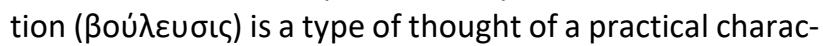
ter, which leads a person to the resolve to act. Delibera-

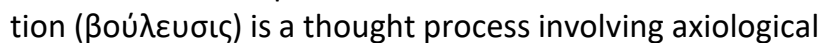
judgment. Karamanolis is certain that "every individual moral virtue proceeds from a specific deliberation

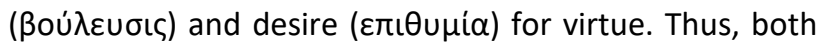

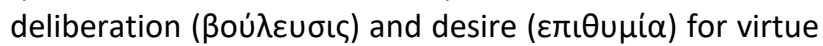

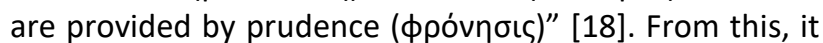
is evident that prudence ( $\phi \rho \operatorname{vo}_{\eta} \sigma \iota \varsigma$ ) is the essence of the moral virtue.

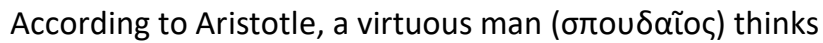
correctly and differentiates between good and apparent good. He therefore states: "For the good man judges everything correctly; what things truly are, that they seem to him to be, in every department, for the noble and the pleasant have a special form corresponding to each of the faculties of our nature, and perhaps what chiefly distinguishes the good man is that he sees the truth in each kind..." [2].

\section{PRUDENCE AND INNOVATION}

Prudence (phronesis) is therefore the essence of virtue and a combination of ethical and dianoetic order. Phronesis understood in this way is a desirable character of both the creators of broadly understood innovations, also in the field of production engineering, as well as 
specialists from the scope of Technology Assessment. In the era of renaissance of the ethics of virtues, it is worth pointing out the relationship between prudence and innovation in contemporary discussion on this subject. A renewed interest in the ethics of virtues is associated with the appeal of Elizabeth Anscombe, contained in the article "Modern Moral Philosophy" (1958). Anscombe states that contemporary moral philosophy, despite the fact that it appeals to Aristotle's thought, in its interpretations distances far from them [1] $]^{3}$. She indicates that one should return to Aristotle's reflections on the "category of good life, human perfection, moral disposition - virtues" [25]. Today, the ethics of virtues is present in the scientific discussion and is invoked alongside deontologism or situationism. These issues are also discussed in the discussions on the axiological aspects of sustainable development, as innovations are an integral part of this concept, detailed among others in such documents as Agenda 21 (1992), the Johannesburg Implementation Plan (2002), Future we Want (2012), the New Agenda for Sustainable Development until 2030 (2015).

Innovations (alike technological, process as well as social) in the concept of sustainable development are treated as a value and are intended to contribute to the improvement of the quality of life, well-being and protection of the natural environment, thus creating preconditions (though not enough) for a good life in Aristotelian understanding. As a consequence, they can also contribute to the achievement of human well-being, characterized by a high level of life satisfaction. Research on human well-being is the subject of scientific research in positive psychology, and this also refers to the Aristotelian theory of virtues and eudaimonies, which Aristotle regarded as the highest good, the most important goal, some optimum, human perfection according to his nature, and thus full of happiness [26]. In the concept of sustainable development, innovations become an instrumental value and a tool for shaping better living conditions, work, learning, rest, all forms of human activity and environmental protection. In the documents mentioned above, constituting the concept of sustainable development, we refer to innovations in economics, finance, teaching, social inclusion, entrepreneurship and the already mentioned technological innovations regarding economic development (including eco-innovation) as well as the development of the information society [21]. Each "innovation product" or "innovation process" is fraught with risk, which is why the virtue of Phronesis (prudence, practical wisdom, sense) is so important both at the stage of designing, as well as production, implementation and finally use. Everyone involved in these processes should undertake a risk assessment and take appropriate measures to minimize the risk of adverse effects. In this sense, prudence is combined with caution and responsibility, or else - prudence is directed by cautious (thoughtful) and responsible human actions. Caution is not understood here as a lack of courage, cowardice, but as a prudent, rational risk assessment, which if it exceeds the acceptable level should result in withdrawal, discontinuation of innovation processes. However, this is not a question of using the Jonas "fear heuristics", which assumes that "all new projects and ideas must be considered in accordance with the principle of the primacy of the failure to forecast a successful" $[9,16]$. Such an approach would block development and to a large extent would make the functioning of man in technical civilization much more difficult. However, taking Jonas' "imperative of responsibility" into account ("Act in such a way that the effects of your actions do not affect the future existence of man on Earth") $[16,17,22]$ is the voice of 'practical wisdom' - phronesis. Prudence, caution and responsibility can be regarded as the virtues of character, although the latter is unknown to the ancient philosophical tradition. In antiquity it was born on a juridical basis, and philosophy and ethics only discovered it in the 18th and 19th centuries due to deliberations by Kant, Schelling, Fichte, Hegel, Kierkegaard or Nietzsche [11]. In the $20^{\text {th }}$ and $21^{\text {st }}$ century, numerous scientific studies were developed regarding the category of responsibility, both its individual and collective dimensions as well as the institutional one.

\section{INSTEAD OF SUMMARY}

Currently, a great emphasis is put on the evaluation of modern technologies and the valuation of science and technology. The German technical philosopher Günter Ropohl, stressing the relational nature of responsibility, points out, inter alia, that the subject of the action is responsible for the effects of his action [23]. Within the European Union, the RRI (Research Responsibility and Innovation) project is being developed. RRI is a process that takes into account the potential impact and effects of research and innovation on the environment and society. As a transparent and interactive RRI process, it takes into account the positions of all social actors (scientists, citizens, politicians, entrepreneurs, non-governmental organizations, etc.) who collaborate throughout the research and innovation process to determine, among others, ethics, scientific and technological achievements [19]. But even such a process of evaluation and exchange of views will not bring positive results if the entities participating in it are not adequately prepared for it. Appropriate preparation should be understood here as the process of ethical education shaping, among others, such character traits as prudence, caution and responsibility recognized as virtues, or permanent, wellestablished human dispositions to act in accordance with the ethical good. From the above considerations follows the postulate of ethical human education at every stage of knowledge acquisition. This is especially important in the education of engineers who shape the innovative landscape of the present and applies equally to mechatronics or robotics specialists as well as production engineering, because the ethical approach allows for proper designing of the entire set of activities from

\footnotetext{
${ }^{3}$ Such a thesis also is put forward and argued by, having recalled the positions of Anglo-Saxon researchers, L. Skowroński [24].
} 
recognizing the need to satisfying it through an efficient, well-prepared, organized and properly managed production process, taking into account the basic principles of sustainable development.

\section{REFERENCES}

[1] G. E. M. Anscombe, "Modern Moral Philosophy", Philosophy. The Journal of the Royal Institute of Philosophy, Vol. 33, No. 124. (Jan., 1958), pp. 1-19. http://stevewatson.info/readings/philosophical_notes/A nscombe-mmp.pdf:Available (December 9, 2018)

[2] I. Bywater. (Ed.). Aristotelis Ethica Nicomachea. Cambridge: Cambridge University Press. 2010.

[3] P. Aubenque. La prudence chez Aristote. Paris: Presses Universitaires de France, 1963.

[4] K. Boháček. Phronesis and Free Decision. Filozofia, 71, 2016, No. 5, pp. 391.

[5] R. Brázda. "Ctnost" in: Filosofický slovník. Kolektiv autorů, Ed. Olomouc: Nakladatelství Olomouc, 2002, p. 72.

[6] S. Broadie. Ethics with Aristotle. New York: Oxford University Press, 1991.

[7] I. Bywater. (Ed.). Aristotelis Ethica Nicomachea. Cambridge: Cambridge University Press. 2010.

[8] J. Cepko. “Fronésis v Platónovom dialógu „Menón“”. Filosofický časopis, vol. 5 pp. 691-705, 2017.

[9] H. Ciążela, "Etyka odpowiedzialności Hansa Jonasa a „trwały i zrównoważony rozwój” (Imperatywy i dylematy)", Problemy Ekorozwoju, vol. 1 No 2, pp. 107-114, 2006.

[10] J. M. Cooper. Reason and Human Good in Aristotle. Cambridge, Mass. and London: Harvard University Press, 1975.

[11] T. Engberg-Pedersen. Aristotle's Theory of Moral Insight. Oxford: Oxford University Press, 1983.

[12] J. Filek. Ontologizacja odpowiedzialności: analityczne i historyczne wprowadzenie w problematykę. Kraków: Wydawnictwo Baran i Suszczyński, 1996.

[13] Fraňo, P. Prudentia in the Writings of Marcus Tullius Cicero, Filozofia, 71, 2016, No. 5, pp. 406.

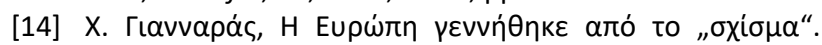

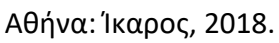

dr hab. Aleksandra Kuzior, prof. PŚ.

Silesian University of Technology

Faculty of Organization and Management

Department of Applied Social Sciences

ul. Roosevelta 26, 41-800 Zabrze, Poland

e-mail: Aleksandra.Kuzior@polsl.pl

prof. ThDr. Ján Zozulak, PhD.

Constantine the Philosopher University in Nitra

Faculty of Arts

Department of Philosophy

Štefánikova 67, 94974 Nitra, Slovak Republic

e-mail: jzozulak@ukf.sk
[15] T. Irwin. Aristotle's Nicomachean Ethics (translation and notes). Indianapolis: Hackett Publishing Company, 1985.

[16] H. Jonas. Zasada odpowiedzialności: etyka dla cywilizacji technologicznej. Kraków: Platan, 1996.

[17] H. Jonas. The Imperative of Responsibility, in Search of an Ethics for the Technological Age. Chicago - Londyn: University of Chicago Press, 1984.

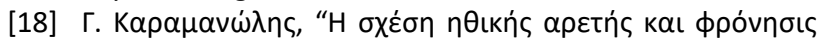

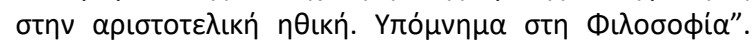
AӨńva, vol. 8, pp. 51-78, June 2009.

[19] A. Kiepas. Filozofia techniki w dobie nowych mediów. Katowice: Wydaw. Uniwersytetu Śląskiego, 2017.

[20] V. Konrádová, "Fronésis a problém zvažování". Filosofický časopis, vol. 5, pp. 707-719, 2017.

[21] A. Kuzior. Aksjologia zrównoważonego rozwoju. Bańska Bystrzyca: Belianum, 2014.

[22] A. Pawłowski. "Wielowymiarowość rozwoju zrównoważonego". Problemy Ekorozwoju, vol. 1, No 1, pp. 23-32, 2006.

[23] G. Ropohl. "Etyka techniki", in: Człowiek, technika, środowisko. Człowiek współczesny wobec wyzwań końca wieku, 1nd ed., A. Kiepas, Ed. Katowice: Uniwersytet Śląski. Instytut Filozofii, 1999, pp. 93-107.

[24] L. Skowroński. "Dlaczego konieczne jest nowe polskie tłumaczenie Etyki nikomachejskiej Arystotelesa?" Archiwum Historii Filozofii I Myśli Społecznej, Archive of the History of Philosophy and Social Thought, vol. 56/2011, pp. 53-68.

[25] N. Szutta. (2004, September) "Status współczesnej etyki cnót". Diametros [Online] 1, pp. s. 70-84. Available: https://www.diametros.iphils.uj.edu.pl/index.php/diametros/article/view/17/13 [Dec. 9, 2018]. DOI https://doi.org/10.13153/diam.1.2004.17

[26] W. Tatarkiewicz. Historia filozofii, t. I. Warszawa: Państwowe Wydawnictwo Naukowe, 1988, s. 118-119.

[27] R. R. Walzer, J. M. Mingay (edd.). Aristotelis Ethica Eudemia. Oxford: Clarendon Press, 1991.

[28] U. Wollner. Opposition Sophrosyne - Phronesis in Plato's Callicles. Filozofia, 71, 2016, No. 5, pp. 370. 